\title{
STEVE SEPP, TASTY! TASTY!
}

\author{
No meanfeast.
}

\section{BY MATTHEW SANBORN SMITH}

W e didn't eat Steve on a Tuesday, which I think was one of the things that made him special.

Steve Sepp - he was one of those all-time losers you talk about to make your own life seem bearable. Lived in a mobile home that hadn't run in a year and a half (that was what he called his car, anyway); couldn't get work; divorced; running from everybody. You didn't want to hang with the guy, because you didn't want to catch whatever he had, you know what I mean? But I felt bad for him and other people did too. The wife would bring him a loaf of bread she baked or some corn muffins or whatever, usually Tuesday nights when we were on our way to the hospital.

This one night though, Steve's sick as a dog, doubled over in pain. He took it until he couldn't take it anymore, which wasn't long really, 'cause Steve was a major wuss on top of all his other problems. Mira and I, we hustle him over to the ER. Nurse asks a couple questions, presses her hand against his belly button. "Might be your appendix," she says, and they grab a wheelchair and whisk him off.

Of course, of all the people we know, Steve was the guy who gets appendicitis. That's his luck. "Well, at least he doesn't have to wait," I says to Mira. She slaps my arm and we head to the south end of the building where we wanted to go in the first place.

The Baker Street Hospital is the place to go on Tuesday nights if you aren't already sick. Tuesday's usually their biggest outpatient day and the Outpatient Diner is what draws people from all over the neighbourhood and beyond. All those little bits and pieces they cut off of people during the day, they wind up on the menu. You know, stew, pulledmeat sandwiches, what have you. If you're an outpatient, you get a freebie after your surgery. Most of 'em want a bite of them-

$\rightarrow$ NATURE.COM

Follow Futures on

Facebook at:

go.nature.com/mtoodm selves. You could call it cannibalism I suppose, but everyone who was on that menu was up and walking around (or wheeling around). The hospital has the waivers. It's all on the up and up.

Not having any insurance, Steve signed the waivers without a blink because it defrayed some of his costs. Not a lot, but every little bit helps. He was in the hole as it was. If he lived through this, it would kill him.

So, like I say, Tuesday nights are hopping at the diner. It got so that regulars like me and Mira couldn't even get in. We're getting

'em like it's the south or somethin', only it's brown gravy. Anyway we taste 'em and me and Mira, our eyes bug out.

"What is this?" I ask him. And he says: "It's Steve Sepp gravy! Steve from down the street? They musta brought him in for somethin."

"Yeah," I says, "Mira and me. We brought him in last night."

"You hear that, everybody?" Jimmy Palbro yells. "Al and Mira are the ones who brought Steve in!" And they're hollerin' and applaudin' like we're the ones who made him sick.

Generally, you go down to the diner, you meet your buddies, the regulars, and you talk about the Sox or politics or whatnot, but this Wednesday, and I remember it like it was yesterday, this Wednesday all we can talk about is Steve. Holy Jesus, you should have tasted him on the mashed potatoes! When they wheeled him in for his share, the chef actually announced him and I tell you, we stood up and clapped and whistled louder than before. $\mathrm{He}$ coulda run for friggin' mayor that day. We would've carried him to his office on our shoulders. And he knew it too.

He's sittin' there in his wheelchair, lookin' skin-boney, like he always has, miserable as hell, and when he really gets it, that we're clapping for him, he sits up straighter. He even smiles. Well, with what teeth he has.

Somebody hands him a little plate of potatoes covered in himself. That was like a feast to Steve, even on a good day. The whole place gets quiet, and we're just standing there, watching him. The nurse gives him a spoon and he gets a little scoop, he's

bumped by celebrities, for chrissakes, like the guy who does Sharona LaHaye's hair and that pip who sells Maxi all her pet supplies.

So we give up and go back on Wednesday, hoping maybe to get a discount on day-old spleen soup or something, I don't know what we were thinking, but we were glad we did. 'Scuse me, my mouth is watering just remembering it.

We walk in not knowing what's what and the place is nuts. Jimmy Palbro runs up to us before we even sit down, and says, he says, "Al, Mira, you guys gotta try this!" He's got a couple of biscuits with some gravy on shakin' a little, and he puts it in his mouth and you can see his eyes get really wide. And he works his mouth a couple of times, but you don't really gotta chew it, you know that hospital stuff is basically mush, but he works it and he swallows and he goes to everybody: "I'm really good!"

And the whole house goes crazy! •

Matthew Sanborn Smith's work has appeared at Tor.com and in Chizine, GUD Magazine and the StarShipSofa podcast. He podcasts at http:// bewarethehairymango.com. 